\title{
Effect of Immunostimulator Baypamun® on Plasma Cortisol Concentration in Gilts Regrouped during the Late Stage of Pregnancy
}

\author{
Ž. PAVIČIĆ ${ }^{1}$, M. VUČEMILO ${ }^{1}$, A. TOFANT ${ }^{1}$, N. VIJTIUK ${ }^{2}$, M. POPOVIĆ ${ }^{2}$, \\ M. BALENOVIĆ ${ }^{3}$, T. BALENOVIĆ 4 \\ ${ }^{1}$ Department of Animal Hygiene, Environment and Ethology \\ ${ }^{2}$ Department of Biology, Faculty of Veterinary Medicine, University of Zagreb, Zagreb, Croatia \\ ${ }^{3}$ Croatian Veterinary Institute, Zagreb, Croatia \\ ${ }^{4}$ Department of Stockbreeding, Faculty of Veterinary Medicine, University of Zagreb, Zagreb, Croatia
}

Received June 26, 2002

Accepted September 22, 2003

Abstract

Pavičić Ž., M. Vučemilo, A. Tofant, N. Vijtiuk, M. Popović, M. Balenović, T. Balenović: Effect of Immunostimulator Baypamun ${ }^{\circ}$ on Plasma Cortisol Concentration in Gilts Regrouped during the Late Stage of Pregnancy. Acta Vet. Brno 2003, 72: 509-514.

Baypamun ${ }^{\circledR}(\mathrm{BPM})$ preparation (Bayer, Germany) is a virus-based immunostimulator, proved to diminish stress consequences by stimulating immunity and thus compensating/decreasing the immunosuppressive effect of endogenous cortisol. The aim of these investigations was to check whether or not the treatment of gilts with BPM before their transfer from the prefarrowing to farrowing house could indirectly prevent an increase of plasma cortisol by inducing non-specific immunity. The study comprised 40 one-year-old gilts of Swedish Landrace breed in late phase of pregnancy assigned into four groups of 10 animals each. Group 1 was sampled before transfer (Day 0 ) and served as a negative control. A positive control (Group 2) was transferred (at Day 0) to the farrowing unit, and then, blood samples were taken at D 1, 3 and 5 following the transfer. Groups 3 and 4 were treated intramuscularly (i.m.) with $2 \mathrm{ml}$ of BPM at D 3 and 1, or 7 and 5, respectively, prior to the transfer, and sampled the same d as Group 2 . Significantly lower levels of cortisol $(P<$ 0.05 ) were recorded at D 3 (after the transfer) in the gilts from Groups 3 and 4, compared to the values obtained for the gilts from Group 2. Moreover, the preparation compensated for severe increase of cortisol in the gilts from Group 3 at D 1 immediately after the transfer. Accordingly, BPM could be recommended for the prophylactic use as anti-stress preparation for the exposure of swine to the acute stress due to regrouping.

Pregnancy, gilts, Baypamun®, plasma cortisol, stress, housing

In intensive pig-breeding the sows are placed in the farrowing crates in the period of farrowing and during lactation. This type of housing for sows, widely accepted in the world, decreases piglet losses caused by crushing (Cronin et al. 1991), but reduces and narrows the living space of sows. That causes stress, which is the reaction of organism to harmful environmental disturbances (Dantzer 1988; Topel and Christian 1986). Stress is the final stage of physiological regulation of animal reactions to harmful actions of its environment (Fraser 1975). In cattle-breeding, the word stress is used for describing the status, which leads to losses in production (Dantzer and Mormede 1983). Namely, occurrence of stress before and during the farrowing contributes to problems in production. Stress hormones may influence the effects of reproductive hormones (Hansen and Curtis 1981). It may prolong pregnancy, as well as increase percentage of dead-born piglets. Corticosteroids are the one group between many hormones secreted during the stress syndrome (Roth 1989). Among them, cortisol has the strongest activity (Rijnberk and Mol 1989). Therefore, its concentration in blood plasma is used as one of the biochemical indicators of stress in pigs (Cronin et al. 1991; Law rence et al. 1994; Blackshaw 1994). It is well-known that an increased concentration of corticosteroids in blood slows down proliferation of lymphocytes (Kelley 1988), decreases quantity of produced antibodies and size of lymph nodes (Martin 1987) and decreases the

Address for correspondence:

Dr. sc. Željko Pavičić

Department of Animal Hygiene,Environment and Ethology

eterinary Medicine, University of Zagreb

Heinzelova 55, 10000 Zagreb, Croatia
Phone: +38512390295

Fax: +38512441390

http://www.vfu.cz/acta-vet/actavet.htm 
ability of pig to resist infection (English and Edwards 1992). Various possibilities of reducing the stress factors are presently widely investigated. Immunomodulator Baypamun ${ }^{\circledR}$ (BPM) has been proved effective in immunostimulation as well as in improving reproduction and production performance in swine(Cutler andPrime 1988; Steinmasl and Wolf 1990; Valpotić et al. 1993; Kyriakis et al. 1996; Krsnik et al. 1999). One of the most vulnerable phases in the technology of industrial pig-breeding is transfer of the late-pregnant gilts from the prefarrowing to farrowing house. That is usually followed by the high risk of acute stress and consequences, which may affect immunocompetence of the gilts themselves and of their offspring. It can also affect normal farrowing and the behaviour of gilts during lactation.

The aim of these investigations was to check whether or not the treatment of gilts with BPM before their transfer from the prefarrowing to farrowing house could indirectly prevent an increase of plasma cortisol by inducing non-specific immunity.

\section{Materials and Methods}

The study comprised 40 pregnant gilts of Swedish Landrace breed, $365 \pm 15$ days old. The criteria for their selection were: the minimal body weight of $85 \mathrm{~kg}$, phenotypic characteristics related to breed and minimal back bacon thickness of $20 \mathrm{~mm}$. All the gilts were vaccinated against erysipelas, atrophic rhinitis, Aujeszky-disease, paravirosis, swine flu, respiratory and reproductive syndrome between 110-190 d of age. Protective vaccination against neonatal colibacillosis and clostridia enterotoxaemia was performed on d 90 of pregnancy.

Selected gilts were assigned to 4 groups comprising 10 animals each. In order to obtain insight into plasma cortisol concentration before the exposure of gilts to the stress of regrouping, blood samples were taken from 10 animals at D 0, before transfer from the prefarrowing to farrowing unit. These gilts were assigned to Group 1 and considered as a negative control group, which was not further sampled during the study. Second group of gilts (Group 2) served as a positive control. These animals were transferred to the farrowing unit and sampled at D 1, 3 and 5 following the transfer. Two $\mathrm{ml}$ of BPM $\left(10^{6.75}\right.$ TCID inactivated stock $1701 \mathrm{D}$ of Parapoxovis virus; Bayer, Germany) were administered i.m. to the gilts in Group 3 at D 3 and 1, as well as to the gilts in Group 4 at D 7 and 5 , prior to their transfer from the prefarrowing to farrowing unit. Both groups of gilts received BPM in the early morning, immediately after the animals had been fed (8:30 to 9:00 hours a.m.).

The gilts were fed meals containing $12.5 \mathrm{MJ}$ of digestible energy, $16 \%$ raw protein, $1 \%$ calcium and $0.6 \%$ total phosphorus per $\mathrm{kg}$. Daily amount of food per gilt was $1.6 \mathrm{~kg}$ up to d of diagnosing of pregnancy, $1.8 \mathrm{~kg}$ up to $\mathrm{d} 60$, $2.4 \mathrm{~kg}$ up to $\mathrm{d} 80$, and $3.0 \mathrm{~kg}$ up to $\mathrm{d} 110$ of pregnancy. Since d 111 of pregnancy, during the anticipation of farrowing, the daily amount of food given was decreased gradually.

The pregnant gilts have been housed during $70 \mathrm{~d}$ before transfer to farrowing units in common prefarrowing units of $16 \mathrm{~m}^{2}$ suitable for housing of 6 gilts. At D 4 prior to expected farrowing, they were transferred by moving on their own to the single farrowing crates for the sow through $15 \mathrm{~m}$ long hall connecting the prefarrowing and farrowing units. The length and width of a single farrowing crate was $2.15 \mathrm{~m}$ and $1.65 \mathrm{~m}$, respectively. The middle part of the farrowing crate for sow was $0.65 \mathrm{~m}$ wide; left and right parts for piglets were $0.40 \mathrm{~m}$ and $0.60 \mathrm{~m}$ wide, respectively.

Blood was taken from the gilts in the Group 1 immediately before transfer from the prefarrowing to farrowing unit, i.e. at 10 hours a.m. (D 0). Groups 2, 3 and 4, were bled at D 1, 3 and 5 after transfer to the farrowing unit. At $\mathrm{d} 1$, blood was taken at $10.30 \mathrm{~h}$ a.m., immediately after the gilts had been transferred from the prefarrowing to farrowing unit. At D 3 and 5, blood was taken at $08.30 \mathrm{~h}$, after the gilts had been fed. Prior to blood sampling the sows were immobilized using a wire nose loop. Blood was taken from the vena cava cranialis, $5 \mathrm{ml}$ per dose and gilt. Disinfection of the sampling site was done just before taking the blood. Blood samples were kept at room temperature for half an hour and then centrifuged at $3500 \mathrm{rpm}$ for $10 \mathrm{~min}$. Blood plasma was transferred into sterile bottles and frozen at $-20^{\circ} \mathrm{C}$. Plasma cortisol was determined by radio immunoassay (RIA) as described earlier (Hasler et al. 1976) using the reagents of Department of Immunology, Zagreb, Croatia. The accuracy of the test was $89.9 \%, 88.4 \%$ and $89.1 \%$ at the concentrations of $256 \pm 26 \mathrm{nmol} / 1,180 \pm 21 \mathrm{nmol} / 1$ and $492 \pm 54 \mathrm{nmol} / 1$, respectively. Lower detection limit was $27 \mathrm{nmol} / \mathrm{l}$.

The obtained data for the plasma concentration of cortisol within the groups of gilts were compared using oneway analysis of variance.

\section{Results}

By comparing the results of the control Group 1 and the other three groups for the plasma concentration of cortisol at D 1 (Table 1; Fig. 1), we found that a significant difference $(P<$ $0.05)$ occurred between control Group 1 and Group 4. According to the average results, the highest concentration of plasma cortisol of $295.3 \mathrm{nmol} / \mathrm{l}$ was found in Group 4, and the lowest of $137.10 \mathrm{nmol} / \mathrm{l}$ in control Group 1 (Table 1; Fig. 1). 
Table 1

Mean $( \pm S D)$ values of plasma cortisol in gilts* treated with BPM prior to the transfer from prefarrowing to farrowing unit

\begin{tabular}{|c|c|c|c|c|c|c|}
\hline \multirow[t]{2}{*}{ Group No. } & \multirow{2}{*}{$\begin{array}{l}\text { Treatment } \\
\text { (days prior } \\
\text { to transfer }\end{array}$} & \multirow[t]{2}{*}{$\begin{array}{c}\text { Blood } \\
\text { sampling }\end{array}$} & \multicolumn{4}{|c|}{$\begin{array}{l}\text { Concentration of plasma cortisol (nmol/L) } \\
\text { at day }\end{array}$} \\
\hline & & & 0 & 1 & 3 & 5 \\
\hline 1 & None & $\begin{array}{c}\text { Before } \\
\text { transfer } \\
\text { (at Day 0) }\end{array}$ & $\begin{array}{l}137.1 \\
\pm 95\end{array}$ & NT & NT & NT \\
\hline 2 & None & After & NT & $\begin{array}{ll} & \text { a,b } \\
224 & \\
\pm 95 & \end{array}$ & $\begin{array}{c}241.3 \\
\pm 86\end{array}$ & $\begin{array}{r}162.1 \\
\pm 142\end{array}$ \\
\hline 3 & $\begin{array}{l}\text { BPM } \\
(-3 /-1)\end{array}$ & $\begin{array}{c}\text { transfer } \\
\text { (at Days } \\
1,3\end{array}$ & NT & $\begin{array}{r}\quad b \\
295.3 \\
\pm 123.7\end{array}$ & $\begin{array}{r}212 \\
212, b \\
\pm 73.6\end{array}$ & $\begin{array}{r}215 \\
\pm 98.4\end{array}$ \\
\hline 4 & $\begin{array}{l}\text { BPM } \\
(-7 /-5)\end{array}$ & and 5) & NT & $\begin{array}{r}185 \\
185 \\
\pm 72.1\end{array}$ & $\begin{array}{ll} & a, b \\
194 & \\
\pm 86 & \end{array}$ & $\begin{array}{l}223.1 \\
\pm 134\end{array}$ \\
\hline
\end{tabular}

* Groups comprised 10 gilts each

** Not tested

$\mathrm{a}, \mathrm{b}-$ mean values with different letters in superscript differed significantly at $P<0.05$

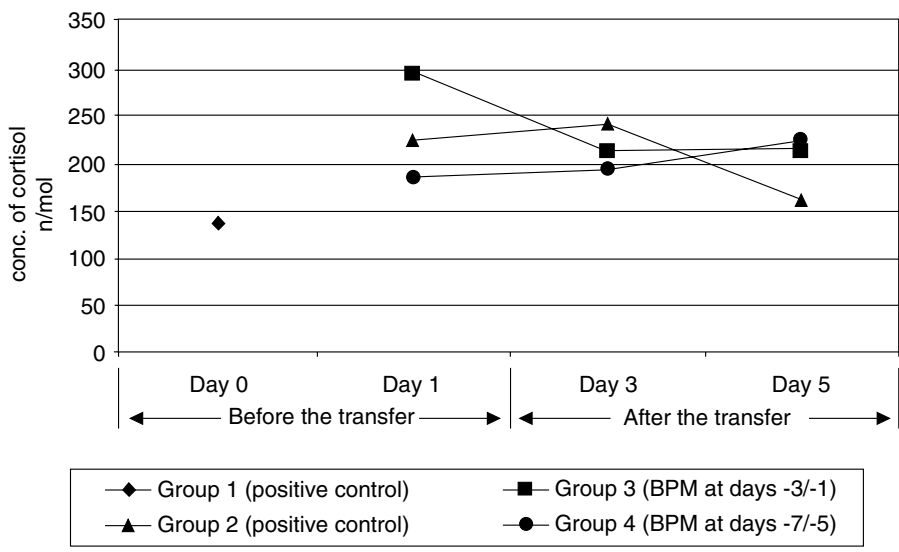

Fig 1. Time course of plasma cortisol concentrations in gilts treated with BPM before the transfer from prefarrowing to farrowing unit.

Significantly lower cortisol concentrations $(P<0.05)$ were recorded at D 3 in the gilts of Groups 3 and 4 as compared to the values obtained for the gilts from Group 2, which served as non-treated control. Moreover, the preparation compensated a severe increase of cortisol in the gilts of Group 3 at D 1 immediately after the transfer. Accordingly, it seems likely that BPM given prophylactically may act as anti-stress preparation within D 1 and 3 following the exposure of swine to the acute stress due to regrouping.

\section{Discussion}

Baypamun ${ }^{\circledR}$ (Bayer, Germany) is an inducer of paraimmunity, obtained by preparation of parapox virus isolated in the sheep affected by pustulous dermatitis and inactivated as described previously (Büttner et al. 1987; Strube et al. 1989). Its efficacy in reduction of 
stress and stimulation of non-specific immunity in pigs was a subject of several investigations (Cutlar and Prime 1988; Steinmasl and Wolf 1990; Valpotić et al. 1993; Kyriakis et al. 1996). Namely, it was found that Baypamun ${ }^{\circledR}$ was effective in prevention or control of infections and alleviation of effects of stress factors, by mechanisms of direct antigenic stimulation of non-specific immunoreaction of an animal that is established within several hours after administration and remains detectable from 8 to $12 \mathrm{~d}$ (Mayr and Büttner 1984).

Application of Baypamun ${ }^{\circledR}$ may increase passively obtained immunity in new-born piglets after non-specific immunization of the pregnant sows and may reduce the losses caused by gastrointestinal syndrome during the perinatal period (V alp o tic et al. 1993). The same authors have found the significantly higher level of total proteins and immunoglobulins in the serum and colostrum of gilts and their piglets treated by Baypamun ${ }^{\circledR}$. That clarifies the earlier standpoints that Baypamun ${ }^{\circledR}$ enhances humoral immunity of gilts and increases their lacteal immunity (Gre gorko et al. 1989). Baypamun ${ }^{\circledR}$ was used in investigation of reproductive performance of the transported gilts, with the conclusion that three-time immunostimulation of gilts during the transport can enhance their reproductive performance, in terms of live-born piglets and average weight of piglets at farrowing (Kyriakis et al. 1996). A similar investigation with Baypamun ${ }^{\circledR}$ proved that two-time immunostimulation of the pregnant gilts before transferring from the prefarrowing to farrowing house may alleviate stress and thus influence decreasing of the share of deadborn piglets in the litter (Krsnik et al. 1999).

Having in mind that transfer from one housing to another causes stress in pregnant sow, we have tried to find if two-time treating of gilts with Baypamun ${ }^{\circledR}$ in different time periods could induce non-specific immunity and thus indirectly influence the immunosuppressive effect of cortisol and its level in plasma.

All the gilts in these investigations were completely integrated in the production technology of the farm, which means that they were protected against the severe specific disease agents by vaccination. However, such scheme did not protect them from stress factors, which may have negative impact on their production performance. From all the gilts in the groups, blood was taken in about the same time during the forenoon (taking in account the limits set by the production technology), because it is known that secretion of corticosteroids is not uniform during day and night (Rijnberk and Mol 1989). If there is not irregular stress situation, the strongest secretion of cortisol in humans, most domestic animals and pigs occurs at the end of the night and at the beginning of the day. The lowest secretion occurs in the late afternoon and during the night (Bottoms et al. 1972; Favre and Moatti 1977; Rijnberk and Mol 1989).

On the basis of the obtained results, we may conclude that the average concentration of plasma cortisol in Groups 2, 3 and 4 during the $3 \mathrm{~d}$ of investigation was higher than in Group 1. That is in accordance with investigations of Cronin et al. (1991), who found the concentration of plasma cortisol increased when the gilts were transferred from the prefarrowing to farrowing house. The plasma cortisol concentration of the gilts from Group 3 at D 1 and from Group 4 at D 3 were increased in comparison with Group $1(P<0.05)$. However, the normal levels of plasma cortisol of the conscious pigs, which were determined by RIA method, are 49.7-218 nmol/l (Hannon et al. 1990). Accordingly, we may conclude that the average level of plasma cortisol in the groups of gilts treated by Baypamun ${ }^{\circledR}$ preparation was within the mentioned limits, except Group $3(295.3 \mathrm{nmol} / \mathrm{l})$ at D 1 and Group 4 at D 5 (223 nmol/l). In Group 2, the average level of plasma cortisol was higher at D $1(224 \mathrm{nmol} / \mathrm{l})$ and at D $3(241.3 \mathrm{nmol} / \mathrm{l})$. In Group 4 at D 1, the average plasma cortisol concentration was lower compared with Group 2. Therefore, Baypamun ${ }^{\circledR}$ may have indirectly affected the decreasing of average plasma cortisol concentration in treated groups 
of gilts up to farrowing, through induced non-specific immunity. A small increase of average plasma cortisol in the groups of gilts treated by Baypamun ${ }^{\circledR}$ preparation during D 5, compared to D 3 of investigation, is attributed to farrowing which occurred on D 4 . Therefore, oscillations of average plasma cortisol concentration between groups treated by Baypamun ${ }^{\circledR}$ preparation and the Group 2 at D 5 certainly depended on individual ability of gilts in the group to resist the stress caused by farrowing. Significantly lower levels of cortisol $(P<0.05)$ were recorded at D 3 (after the transfer) in the gilts of Groups 3 and 4 compared to the values obtained for the gilts of Group 2. Moreover, the preparation compensates for severe increase of cortisol in the gilts of Group 3 at D 1 immediately after the transfer. Accordingly, it seems likely that BPM given prophylactically may act as antistress preparation in swine exposed to the acute stress due to regrouping.

The further investigations on indirect influence of Baypamun ${ }^{\circledR}$ preparation on plasma cortisol are needed. Namely, the more precise determination of its influence on the consequences of farrowing stress could be obtained by testing the greater number of treated gilts immediately before and after the farrowing.

\section{Vliv imunostimulátoru Baypamun ${ }^{\circledR}$ na koncentraci kortizolu v plazmě prasnic po přeskupení $\mathrm{v}$ pozdní fázi gravidity}

Přípravek Baypamun® (BPN) (Bayer, Německo) je imunostimulátor na bázi virů, o kterém je prokázáno, že snižuje následky stresu stimulací imunity a tak kompenzuje/snižuje imunosupresivní efekt endogenního kortizolu.Cílem výzkumu bylo ověřit zda medikace prasnic BPM před transportem $\mathrm{z}$ odchovny na porodnu může nepřímo indukcí nespecifické imunity předcházet zvýšení koncentrace kortizolu v plazmě. Studie zahrnovala 40 jednoletých prasnic Švédské Landrasy v pozdní fázi gravidity, jenž byly rozděleny do čtyř skupin po 10 zvíratech. Skupině 1 byly odebrány vzorky krve před transportem (den transportu je označen jako den 0) a sloužily jako negativní kontrola. Pozitivní kontrola (skupina 2) byla transportována na porodnu (v dni 0) a pak byly odebrány vzorky krve 1., 3. a 5. den. Skupiny 3 a 4 byly medikovány $2 \mathrm{ml}$ BPM intramuskulárně tři a jeden, respektive sedm a pět dní před transportem a vzorky krve byly odebrány stejně jako skupině 2. Významně nižší hladiny kortizolu $(P<0,05)$ byly zaznamenány $\mathrm{v}$ den 3 (po transportu) u prasnic ze skupin 3 a 4 [které dostaly BPM v den $-3 /-1$ respektive $-7 /-5$ před transportem (den 0 )] jak ve srovnání s prasnicemi ze skupiny 2 , které sloužily jako nemedikovaná kontrola. Navíc, př́ipravek kompenzoval prudké zvýšení hladiny kortizolu u prasnic ze skupiny $3 \mathrm{v}$ den 1 bezprostředně po transportu. Výsledky pokusu ukazují, že BPM podán profylakticky může působit jako antistresový přípravek během prvního a třetího dne po vystavení prasnic akutnímu stresu, vyvolanému přeskupováním prasnic před porodem.

\section{References}

BLACKSAW, JK, BLACKSHAW, AW, NEWMAN, FW 1994: Comparations of behaviour patterns of sows and litters in farrowing crate and farrowing pen. Appl Anim Behav Sci 39: 281-295

BOTTOMS, GD, ROESEL, OF, RAUSCH, FD, AKINS, EL 1972: Circadian variation in plasma cortisol and corticosterone in pigs and mares. Am J Vet Res 33: 785-790

BUTTNER, M, STRUBE, W, WOLF, G, HOERSTKE, M 1987: Parapoxivirus als Induktor unspezifischer Abwerhrmechanismen. Tierarztl Umsch 42: 14-21

CRONIN, GM, BARNETT, JL, HODGE, FM, SMITH, JA, Mc CALLUM, TH 1991: The welfare of pigs in two farrowing/lactation environments: cortisol responses of sows. Appl Anim Behav 32: 117-127

CUTLER, RS, PRIME, RW 1988: Reducing stillbirths in pigs. Austr Adv Vet Sci 65: 111-113

DANTZER, R, MORMEDE, P 1983: Stress in farm animals, a need for revaluation. J Animl Sci 57: 6-18

DANTZER, R 1988: Le stress chez le porc. Res Med Vet 164: 843-848

ENGLISH, PR, EDWARDS, SA 1992: Animal welfare. In: Diseases of swine (Ed. by DJ TAILOR), pp. 901-908. Iowa State University Press-Ames-Iowa-USA

FAVRE, D, MOATTI, JP 1977: Dosage des corticost, roides plasmatiques chez le porcelet. Ann Rech Vet 8:111-120 FRASER, D 1975: The effects of straw on the behaviour of sows in tether stalls. Anim Prod 21: 59-68 
GREGORKO, V, VALPOTIĆ, I, VRBANAV, I, BAŠIĆ, I 1989: Immunoglobulin and total protein concentrations in sow colostrum and the serum of suckling and weaned pigs. Period Biol 91:52-53

HANNON, JP, BOSSONE, CA, WADE, CH 1990: Normal physiological values for conscious pigs used in sow biomedical research. Lab Anim Sci 40: 293-298

HANSEN, KE, CURTIS, SE 1981: Prepartal activity of sows in stall or pen. J Anim Sci 51: 459-460

KELLEY, KW 1988: Cross - talk between the immune and endocrine systems. J Anim Sci 66: 2095-2108

KRSNIK, B, PAVIČIĆ, Ž, YAMMINE, R, SUŠIĆ, V, BALENOVIĆ, T, POTOČNJAK, D, RADELJEVIĆ, D 1999: Preliminäre Untersuchugen der Verhaltnisse zwischen lebend - und totgeborenen Ferkeln bei Jungsauen, die mit dem Paramunitatsinducer Baypamun ${ }^{\circledR}$ behandelt wurden. Tierarztl Umsch 54: 214-218

KYRIAKIS, SC, ALEXOPOULUS, C, GIANNAKOPOULOS, K, TSINAS, AC, SAOULIDIS, K, KRITAS, S, TSILOYIANNIS, V 1996: Effect of a paraimmunity inducer on reproductive performance of gilts. J Vet Med Ass 43: 483-487

LAWRENCE, AB, PETHERICH, JC, Mc LEAN, KA, DEANS, KA, CHIRNSIDE, LA, VAUGHAN, J, CLUTTON, A, TERLOUW, EMC 1994: The effect of environment on behaviour, plasma cortisol and prolactin in parturient sows. Appl Anim Behav Sci 39: 313-330

MARTIN, P 1987: Psychology and the immune system. New Sci 9: 46-50

MAYR, A, BUTTNER, M 1984: Neue Erkenntnise über die Grundlagen der Paramunität und Paramunisierung. Berl Munch Tieraerztl Wschr 97: 429-435

RIJINBERK, A, MOL, JA 1989: Adrenocortical function. In: Clinical Biochemistry of Domestic Animals (Ed. By JJ KANEKO), pp. 611-626. Academic Press Inc, New York-Boston-London-Tokyo

ROTH, JA 1989: Cortisol as a mediator of stress associated immunosuppression in cattle. In: Animal Stress (Ed. by GP MORGEN) pp. 225-244. Am Physiol Soc Waverley Press, Bethesda-Maryland

STEINMASL, M, WOLF, G 1990: Bildung von interleukin 2 durch mononukleare Leukoyzten des Schweines nach in vitro Stimulation it verschiedenen Viruspräparation. J Vet Med 37: 313-321

STRUBE, W, THEIN, P, KRETZDORN, D, GRUNMACH, J 1989: Baypamun ${ }^{\circledR}$ : New possibilities for the control of infectious diseases in domestic animals. Vet Med Rev 60: 3-15

TOPEL, DG,CHRISTIAN, LL 1986: Porcine stress syndrome. In: Diseases of Swine (Ed by DJ TAILOR) pp. $737-$ 746. Iowa State University Press, Ames-Iowa

VALPOTIĆ, I, VIJTIUK, N, RADELJEVIĆ, D, BILIĆ, V, KRSNIK, B, VRBANAC, I, LAUŠIN, M 1993: Nonspecific immunisation of primiparous sows with Baypamun ${ }^{\circledR}$ enhances lacteal immunity. Vet Arhiv 63: $161-172$ 